\title{
THE TRADE IN WILD LIFE. LICENSING SYSTEMS
}

\author{
By C. L. Boyle
}

In wild life affairs all licensing systems, be they the licensing of hunting, capture, sale of trophies, or anything else, should have the primary purpose of conservation. Assuming that any trade at all in wild animals is justifiable the country concerned should decide the maximum number of animals of each kind which it can spare and may then charge as much as possible for each of them. The basic purpose is to limit the number shot or captured to that which the stock can stand.

The danger of trying to place any game department on a financially self-supporting basis is that when additional funds are needed the department may be told to shoot more elephants on control or issue more game licences. Moreover those who directly pay the piper are likely to demand that they call the tune. Such attitudes can be very dangerous to conservation.

Everywhere there is a great and growing demand for wild animals and control of this trade is liable to take up a disproportionate amount of the time of any game department. Those who wish to capture animals are charged fees for their licences and it is most important that the fees should be based on numbers captured not on numbers exported. Many trappers are content to work on a one-in-ten survival basis and if they have only to pay fees on the one which reaches the point of export, there is little financial incentive to humane practices. If, however, trappers have to pay a fee for each one of the ten captured, they are apt to have a little more regard for the well-being of their captives.

Trappers should not be allowed to keep animals in stock. Licences should only be issued against seen orders from approved institutions.

The following procedure, which is that which Kenya enforces, might well be considered by all other countries where trade in wild animals is allowed :-

(a) The would-be trapper must first obtain a Dealer's Licence from the Game Department, which is only issued subject to knowledge of the applicant and his serving a satisfactory apprenticeship. The names of all assistants who will have anything to do with the handling of animals have to be endorsed on the Dealer's Licence, and these people have also to be approved by the Game Department.

(b) On receipt of an enquiry for an animal the trapper has to make formal application on a standard form and produce the actual letter of enquiry or order.

(c) These applications are considered by the Capture Committee which is advisory to the Chief Game Warden and sits once a month. At present the Committee has representatives from, among others, the Coryndon Museum, Wild Life Society, Veterinary Department, Royal National Parks, Royal College. 
The Capture Committee considers very strictly the suitability of the institution wanting the animal, the availability of the animal, the proposed place, method of capture and other things. Most of the conditions with which the trapper has to comply are printed on the back of the application form.

(d) If the application is approved the trapper is at liberty to take out a Capture Permit from the Game Department at any time he likes, for the particular animal concerned. The fees charged for these permits are at the Game Warden's discretion.

(e) Having captured his animal and complied with all the regulations on the application form, the trapper eventually applies for an Export Permit from the Game Department. This is issued free, but the necessity of obtaining one allows the Game Department to enforce the regulations regarding crating and shipping arrangements.

[Note.-The British Standards Institution (British Standards House, 2 Park Street, London, W. 1) has produced a series of pamphlets on the air shipment of certain wild birds and animals. It provides a useful basis when making regulations. They are BS 3149, Parts 1, 2, 3, 6, 7 and 8, and cost 5s. each.] 